TULIP: Tulisan Ilmiah Pariwisata

E-ISSN: 2720-9873

Available Online at https://journal.umgo.ac.id/index.php/Tulip/index

Vol. 4, No. 1 Juni 2021

DOI: http://dx.doi.org/10.31314/tulip.4.1.6-12.2021

\title{
STRATEGI PELESTARIAN BUDAYA LOKAL SEBAGAI UPAYA PENGEMBANGAN PARIWISATA BUDAYA (SEBAUAH ANALISIS TEORITIS)
}

\section{Desrika Talib, Sri Sunarti,}

Program Studi Pariwisata, Universitas Muhammadiyah Gorontalo, Indonesia

Email;1. srisunarti@umgo.ac.id, 2.desrikatalib@umgo.ac.id

\section{Info Artikel Abstract:}

The purpose of this research is to analyze the strategy of preserving local

Diterima: 20

Mei 2020

Disetujui: 02

Juni 2020 culture as an effort to develop cultural tourism. This study is a form of strategic assessment effort, in order to find solutions in the development of tourist destinations, especially cultural tourism. In this study, the literature review method was used, by collecting several references from previous research related to tourism development and preservation strategies. From the results of the analysis, it was found that one form of strategy that needs to be done is a marketing strategy to increase the number of tourist visits by creating a branding of cultural tourist attractions as a quality tourist attraction, maintaining the culture or customs and characteristics of local communities, conducting promotions via the internet or through the internet. brochures to introduce cultural tourist attractions to be better known by tourists, as well as build an image of tourist attractions to fix problems that result in a decreased number of visits.

Keywords: Strategy; Preservation of local culture; cultural tourism development

\begin{abstract}
Abstrak:
Tujuan penelitian adalah melakukan analisis tentang strategi pelestarian budaya local sebagai upaya pengembangan pariwisata budaya. Kajian ini sebagai bentuk upaya pengkajian strategi, guna menemukan solusi dalam pengembangan destinasi wisata khususnya wisata budaya. Dalam penelitian digunakan metode kajian kepustakaan, dengan mengumpulkan beberapa referensi penelitian terdahulu terkait strategi pengembagan dan pelestarian wisata. Dari hasil analisis ditemukan bahwa salah satu bentuk strategi yang perlu dilakukan adalah strategi pemasaran untuk meningkatkan jumlah kunjungan wisatawan dengan menciptakan branding daya tarik wisata budaya sebagai daya tarik wisata yang berkualitas, mempertahankan budaya atau adat istiadat dan karakteristik masyarakat lokal, melakukan promosi lewat jalur internet maupun brosur untuk memperkenalkan daya tarik wisata budaya agar lebih dikenal oleh wisatawan, serta membangun image daya tarik wisata untuk memperbaiki permasalahan yang mengakibatkan jumlah kunjungan yang menurun.
\end{abstract}

Kata Kunci: Strategi; Pelestarian budaya local; pengembangan pariwisata budaya 


\section{PENDAHULUAN}

Seiring dengan perkembangan teknologi zaman sekarang generasi muda sudah mulai melupakan serta meninggalkan budaya Indonesia yang sangat kaya ini. Globalisasi juga berpengaruh kuat terhadap menurunnya tingkat kepedulian masyarakat untuk menjaga dan melestarikan budaya Indonesia. Indonesia terdiri dari berbagai macam suku dengan budaya yang berbedabeda. Perkembangan jaman dan kemajuan pembangunan berdampak pada perubahan sosial. Di berbagai wilayah khususnya perkotaan dan daerah penyangga (buffer space) struktur masyarakat mengalami perubahan dari homogen menjadi heterogen sebagai akibat adanya arus urbanisasi. Pola hubungan juga mengalami perubahan, dari patembayan atau kerukunan dengan asas resiprokal (saling tolong menolong) berubah menjadi individualis dan berdasar asas kepentingan.

Penelitian ini ingin melihat strategi pelestarian budaya lokal khususnya yang bermakna kesetiakawanan sosial. Unsur kebersamaan dalam masyarakat merupakan sifat yang membangun kesetiakawanan sosial. Nilai-nilai kesetiakawanan sosial di era sekarang masih banyak kita jumpai terutama di daerah perdesaan. Di perdesaan nilai kesetiakawanan sosial masih dilestarikan oleh masyarakat, kegiatan gotong royong masih banyak dijumpai seperti membangun rumah, kerja bakti dan membantu orang yang sedang hajatan atau orang meninggal dunia.

Pelestarian budaya lokal adalah mempertahankan nilai-nilai seni budaya, nilai tradisional dengan mengembangkan perwujudan yang bersifat dinamis, serta menyesuaikan dengan situasi dan kondisi yang selalu berubah dan berkembang. Salah satu tujuan diadakannya pelestarian budaya adalah juga untuk melakukan revitalisasi budaya (penguatan). Mengenai revitalisasi budaya Alwasilah mengatakan adanya tiga langkah, yaitu : (1) pemahaman untuk menimbulkan kesadaran, (2) perencanaan secara kolektif, dan (2) pembangkitan kreatifitas kebudyaaan.

Pariwisata budaya merupakan salah satu sektor wisata yang banyak dikembangkan oleh pemerintah daerah akhirakhir ini. pariwisata budaya adalah salah satu jenis pariwisata yang menjadikan budaya sebagai daya tarik utama. Dimana di dalam pariwisata budaya ini wisatawan akan diapndu untuk disamping mengenali sekaligus memahami budaya dan kearifan pada komunitas lokal tersebut. Disamping itu, pengunjung akan dimanjakan dengan pemandangan, tempat-tempat bersejarah sekaligus museum, representasi nilai dan sistem hidup masyarakat lokal, seni (baik seni pertunjukan atau pun seni lainnya), serta kuliner khas dari masyarakat asli atau masyarakat lokal yang bersangkutan.

pariwisata budaya mencakup semua aspek dalam perjalanan untuk saling mempelajari gaya hidup maupun pemikiran. Definisi ini lebih mengarah pada tujuan pengunjung/atau wisatawan mengunjungi wisata budaya lebih pada untuk memahami hakikat dan membandingkannya dengan kondisi budaya yang dimilikinya sebagai sebuah pemahaman baru, tentunya disamping adanya nilai estetika yang terkandung di dalamnya.

\section{HASIL DAN PEMBAHASAN}

\section{A. Konsep Stratei dan Pelestarian \\ a. Strategi}

Srategi pemasaran atau marketing startegy dapat mempunyai tafsiran bermacam-macam, hingga pemakaian konsep yang jelas menjadi amat perlu. Oleh karena itu, penting rasanya kita memahami pendapat 
para ahli tentang definisi strategi pemasaran.(Ariwibowo, 2019)

Berikut adalah definisi strategi pemasaran menurut para ahli :

1. Strategi Pemasaran Menurut Stanton

Stanton merupakan seorang yang berprofesi sebagai dosen dan analis ekonomi, dalam bukunya yang berjudul "prinsip prinsip ekonom", ia mendefinisikan strategi pemasaran sebagai sesuatu yang melingkupi semua sistem yang memiliki hubungan dengan tujuan untuk merencanakan dan menentukan harga hingga mempromosikan dan menyalurkan produk (barang atau jasa) yang dapat memuaskan konsumen. (Stanton, 2001)

2. Strategi Pemasaran Menurut Philip Kotler

Kotler merupakan seorang American marketing author, consultant, and professor, dalam bukunya yang berjudul "Marketing Management, The Millenium Edition", dia mendefinisikan strategi pemasaran sebagai suatu mindset pemasaran yang akan digunakan untuk mencapai tujuan pemasaran, dimana di dalamnya terdapat strategi rinci mengenai pasar sasaran, penetapan posisi, bauran pemasaran, dan budget untuk pemasaran. (Philip Kotler, 2000)

3. Strategi Pemasaran Menurut Fandy Tjiptono

Tjiptono merupakan seorang dosen senior di School of Business, Monash University Malaysia, dalam bukunya yang berjudul " Stratgei Pemasaran Edisi III", ia mendefinisikan strategi pemasaran sebagai alat fundamental yang dirancang untuk mencapai tujuan perusahaan dengan mengembangkan keunggulan daya saing yang berkesinambungan melewati pasar yang dimasuki, dan progam pemasaran yang digunakan untuk melayani pasar target tersebut. (Fandy Tjiptono, 2002)
4. Strategi Pemasaran Menurut Kotler dan Amstrong

Menurut Kotler dan Amstrong merupakan seorang American marketing author, consultant, and professor, dalam bukunya yang berjudul " Prinsip-prinsip Pemasaran. Edisi. 12. Jilid 1" mereka mendefinisikan strategi pemasaran sebagai logika pemasaran dimana unit bisnis berharap untuk menciptakan nilai dan memperoleh keuntungan dari hubungannya dengan konsumen. - (Kotler dan Amstrong, 2008)

5. Strategi Pemasaran Menurut Louis E. Kurt

Louis E. Kurt atau yang akrab dikenal denagn sapaan Kurtz, adalah seorang ahli dalam bidang bisnis, dan bersama dengan rekan-rekannya Boone dan David L, dalam bukunya yang berjudul "Pengantar Bisnis Kontemporer. Buku 1" mendefinisikan strategi pemasaran sebagai keseluruhan program perusahaan dalam menentukan target pasar dan memuaskan konsumen dengan membangun kombinasi elemen dari marketing mix; produk, distribusi, promosi, dan harga. (Louis E. Kurt, 2008)

Berdasarkan pendapat - pendapat para ahli yang telah mendefinisikan strategi dengan latar belakang yang berbeda, maka disini penulis menarik sebuah kesimpulan yang menyatakan bahwa strategi pemasaran adalah pendekatan sumberdaya potensial meliputi peluang dan ancaman dalam pembuatan keputusan atau gagasan yang dapat digunakan untuk perencanaan eksekusi pencapaian target pemasaran yang efektif dan efisien. Pengertian tersebut hanyalah pemahaman penulis yang dapat di klarifikasi oleh para pembaca.

\section{b. Teori Pelestarian}

Pelestarian dalam Kamus Bahasa Indonesia berasal dari kata lestari, yang artinya adalah tetap selama-lamanya tidak 
berubah. Kemudian dalam penggunaan bahasa Indonesia, penggunaan awalan pedan akhiran -an artinya digunakan untuk menggambarkan sebuah proses atau upaya (kata kerja). (Khutniah and Iryanti, 2012)

Pelestarian adalah upaya pengelolaan pusaka melalui kegiatan penelitian, perencanaan, perlindungan, pemeliharaan, pemanfaatan, pengawasan, dan atau pengembangan secara selektif untuk menjaga kesinambungan, keserasian, dan daya dukungnya dalam menjawab dinamika jaman untuk membangun kehidupan bangsa yang lebih berkualitas. (Adishakti, 2016)

Pelestarian adalah sebuah upaya yang berdasar dan dasar ini disebut juga faktorfaktor yang mendukung, baik dari dalam maupun dari luar hal yang dilestarikan. Oleh karena itu, sebuah proses atau tindakan pelestarian mengenal strategi maupun teknik yang didasarkan pada kebutuhan dan kondisinya masingmasing.(Dan et al., 2020)

\section{B. Strategi Dalam Pelestarian Budaya Lokal Sebagai Upaya Pengembangan Pariwisata Budaya}

Kehidupan di wisata budaya pada umumnya telah menggambarkan adanya budaya hidup guyup rukun, di mana setiap anggota masyarakat diharapkan dapat saling tolong menolong dan memiliki rasa kepedulian terhadap sesama. Masyarakat desa secara umum memandang bahwa kesetiakawanan sosial telah menjadi tradisi sebagai kepribadian dan sikap yang perlu dilestarikan. Keberadaan budaya yang ada di masyarakat dapat terjaga dengan baik oleh generasi muda. Pada dasarnya tradisi budaya lokal mengutamakan keselarasan hubungan antarorang perorangan yang terjadi di masyarakat dengan dilandasi prinsip hidup rukun dan saling menghargai serta menghormati satu sama lainnya.
Strategi yang diperlukan masyarakat dalam melestarikan budaya lokal yakni dengan memberikan pembelajaran sosial bagi generasi muda. Pembelajaran yang dimaksud antara lain dapat dilakukan dengan memberikan pendidikan pada generasi muda agar mereka memiliki tanggungjawab untuk berperan aktif dalam melestarikan budaya. Pendidikan tersebut bisa dimulai dengan memberikan kesempatan pada generasi muda untuk belajar berbagai seni budaya yang ada seperti belajar menari, kerawitan dan mengadakan pertunjukan pentas budaya lokal antardusun ataupun desa. Generasi muda diberi kesempatan dan wadah untuk menunjukkan potensi yang dimiliki di bidang seni.

Masyarakat dapat mempertahankan keberadaan budaya tersebut dengan berbagai kegiatan yang ada di masyarakat seperti mengadakan lomba dalam acara tradisi rasulan oleh generasi muda. Kegiatan ini dilakukan dengan tujuan untuk menanamkan rasa solidaritas antarsesama. Hasil wawancara dengan tokoh masyarakat menyebutkan bahwa dalam melestarikan budaya generasi muda tidak hanya mempelajari budaya tersebut, tetapi juga harus mempraktekkannya dalam kehidupan sehari-hari. Masyarakat ikut berpartisipasi apabila ada kegiatan dalam rangka pentas kebudayaan yang diselenggarakan oleh desa setempat.

Pelestarian budaya dapat ditunjukkan dengan mengikuti pentas budaya tradisional pada saat acara tertentu seperti pada peringatan hari ulang tahun kemerdekaan dan hari bersih desa. Budaya sebagai warisan leluhur yang memiliki nilai tinggi bagi kehidupan berbangsa bernegara perlu dilestarikan. Generasi muda sebagai generasi penerus bangsa diharapkan dapat mewarisinya dengan tetap mempelajari dan mencintai budaya tersebut. Hal tersebut 
bertujuan agar budaya yang ada tidak musnah dan dapat berkembang sesuai dengan kondisi saat ini. Menurut informan upaya melestarikan budaya harus sudah tertanam dalam diri setiap individu masyarakat Indonesia. Dengan demikian, tumbuhnya sikap rasa memiliki dan mencintai budaya sendiri akan berpengaruh pada sikap keinginan untuk melestarikan budaya.

Era globalisasi dapat menimbulkan berbagai perubahan, termasuk dalam gaya hidup. Akibatnya masyarakat cenderung memilih kebudayaan baru yang dinilai lebih mudah dan praktis jika diterapkan dibanding budaya lokal.

Oleh karena itu, penting sekali untuk melakukan beberapa upaya melestarikan budaya Indonesia, seperti ulasan berikut ini;

\section{Mempelajari Budaya Lokal}

Salah satu cara untuk melestarikan budaya lokal yaitu dengan memahami budaya itu sendiri. Anda harus mengetahui berbagai macam informasi berkaitan dengan budaya Anda dari berbagai sumber, mulai dari ensiklopedi, buku, bahkan surat kabar. Apalagi, sudah banyak literatur yang membahas tentang kebudayaan Indonesia.

Selain dari literature cetak, Anda juga bisa mempelajari budaya lewat kemudahan akses internet yang ada. Misalnya saja jika Anda orang Jawa yang ingin mengetahui seluk beluk budaya Jawa, maka bisa membaca infonya lewat situs tertentu.

\section{Mengikuti Kegiatan Budaya Asal}

Setelah mengetahui berbagai informasi dan karakteristik dari budaya lokal Anda, selanjutnya yaitu mengikuti kegiatan budaya tersebut. Hal ini merupakan salah satu contoh dalam upaya melestarikan budaya Indonesia.

Anda bisa mengikuti kegiatan budaya dengan terlibat langsung dalam sebuah kontes. Misalnya saja, menjadi peserta atau penonton kegiatan budaya tersebut.
3. Mengenalkan Produk Budaya Ke Kancah Internasional

Selain itu, Anda juga bisa melestarikan budaya dengan cara mengenalkan berbagai kesenian dan budaya melalui jejaring sosial. Anda bisa memperkenalkan budaya khas Indonesia ke dunia luar hanya dengan postingan foto di media sosial.

Caranya bisa dilakukan dengan posting foto kesenian lokal yang dilengkapi dengan deskripsi dua bahasa, yaitu bahasa daerah dan inggris. Tidak hanya itu saja, Anda juga bisa memilih upaya melestarikan budaya Indonesia dengan cara memperkenalkan budaya lokal di kancah internasional.

Caranya yaitu mengenakan produk budaya lokal Jika berada di luar negeri, maka cukup kenakan produk asli Indonesia untuk memperkenalkan budaya lokal. Selain itu, Anda juga harus memilih produk dari Indonesia ketimbang luar negeri.

4. Jadikan Budaya Sebagai Identitas

Menjadikan budaya lokal sebagai identitas menjadi salah satu cara untuk melestarikannya. Sebab, Anda memiliki rasa bangga terhadap budaya lokal yang dimiliki di tengah tengah globalisasi. Dengan begitu, Anda tidak akan mudah terpengaruh atau ikut ikutan terhadap adanya budaya asing yang masuk ke negara Indonesia.

5. Mengekspor Barang Kesenian

Bagi Anda yang seorang pebisnis, maka bisa ikut serta mempromosikan kebudayan lokal melalui produk kesenian yang dijual. Anda dapat mengembangkan usaha yang sedang digeluti agar sampai ke pasar internasional. Jika sudah menembus pasar internasional untuk mengekspor produk kesenian, berarti Anda sudah mencoba upaya melestarikan budaya Indonesia. Kebudayaan merupakan salah satu identitas bagi suatu masyarakat. Selain itu, budaya bisa mempersatukan, memenuhi kebutuhan, dan 
lain sebagainya. Sehingga, sangat penting untuk berupaya melestarikan budaya lokal.

\section{Strategi Pelestarian Budaya Lokal Sebagai Upaya Pengembangan Pariwisata Budaya}

Promosi, sarana fisik, orang dan proses yang dimiliki oleh daya tarik wisata budaya serta mengenai identifikasi terhadap faktor internal dan faktor eksternal terhadap komponen marketing mixyang dimiliki oleh daya tarik wisata tersebut berhubungan dengan marketing mix maka dapat dikemukakan suatu strategi pemasaran yang diterapkan oleh pihak pengelola daya tarik wisata budaya dalam hal ini daya tarik wisata budaya di bawah pengawasan Desa Adat budaya serta kelompok sadar wisata dan didukung oleh kelompok photographer (Polaroid Objek Sangeh) untuk meningkatkan kembali jumlah kunjungan wisatawan ke daya tarik wisata budaya akan dijelaskan dibawah ini :

a. Strategi Strength Opportunites (SO)

Strategi ini berupaya untuk memanfaatkan kekuatan yang dimiliki untuk meraih peluang peluang yang ada di luar atau lingkungan eksternal. Strategi yang dapat diterapkan dalam pemasaran Daya Tarik parwisata budaya adalah menciptakan branding daya tarik wisata sebagai daya tarik wisata budaya yang berkualitas. Brandig atau merk dagang suatu produk atau daya tarik adalah sangat penting agar selalu mengingatkan konsumen akan produk atau daya tarik tersebut. Jika suatu branding ekspresif dan menarik, maka branding tersebut akan tersimpan lama di memori konsumen atau khalayak ramai. Kawasan Alas Pala Sangeh yang menjadi daya tarik wisata dan memiliki potensi pariwisata yang mulai berkembang, sampai saat ini pariwisata budaya belum begitu dikenal oleh karena itu perlunya diciptakan branding untuk memperkenalkan kawasan Daya Tarik pariwisata budaya di nusantara maupun mancanegara.

b. Strategi Strength Threat (ST)

Strategi ini memanfaatkan kekuatan untuk menghadapi ancaman. Strategi yang dapat dilakukan dalam memasarkan Daya Tarik pariwisata budaya adalah dengan mempertahankan keasrian lokal, kebiasaan, karakteristik masyarakat lokal. Dengan mempertahankan keasrian lokal adat istiadat akan meningkatkan jumlah kunjungan wisatawan nusantara maupun mancanegara. Wisatawan mancanegara lebih menyukai wisata budaya atau cultural tourism karena mereka ingin mengetahui kebudayaan atau adat istiadat yang ada di indonesia.

c. Strategi Weakness Opportunities (WO) Strategi ini adalah strategi yang dirancang untuk berusaha meminimalkan kelemahan dengan memanfaatkan peluang yang ada. Strategi pemasaran yang biasa diterapkan adalah mempromosikan daya tarik pariwisata budaya sebagai daya tarik wisata budaya yang berkualitas. Untuk menarik kedatangan wisatawan agar berkunjung ke daya tarik wisata yang sempat ditinggalkan wisatawan sehingga jumlah kunjungan menurun drastis, perlu strategi untuk mempromosikan daya tarik pariwisata buadaya yang memiliki daya tarik wisata yang unik dan berkualitas.

d. Strategi Weakness Threat (WT)

Strategi ini bertujuan untuk bertahan dengan meminimalisir kelemahan dengan menghindari ancaman. Strategi yang dapat diterapkan adalah dengan peningkatan promosi daya tarik wisata budaya dan lebih memperhatikan perawatan kera-kera terutama pola makan yang cukup suapaya kera-kera tidak berbuat nakal dan liar terhadap wisatawan yang berkunjung. Daya Tarik Wisata budaya memiliki potensi yang menarik tetapi karena kurangnya promosi 
mengakibatkan daya tarik ini kurang dikenal di mancanegara. Dalam memasarkan daya tarik wisata budaya agar lebih dikenal di mancanegara pihak pengelola harus lebih giat lagi dalam melakukan kerjasama dengan stakeholder pariwisata. Pihak pengelola juga harus lebih baik lagi dalam mempromosikan lewat jalur internet maupun penyebaran brosur yang didalamnya tercantum sekilas tentang daya tarik wisata budaya, daya tarik yang ditawarkan dan gambaran umum dari daya tarik wisata budaya untuk mengembalikan image daya tarik wisata budaya..

\section{KESIMPULAN}

Desa ini seutuhnya di kelola oleh masyarakat setempat, walaupun tidak semua masyarakat ikut berpartisipasi aktif dalam pengelolaan dan pengembangan desa wisata Malangan. Desa Wisata Malangan merupakan desa wisata yang mengandalkan kearifan lokal yang ada seperti kerajinan, peternakan, dan pertanian. Untuk kegiatan wisata dari pelayanan, pemandu, penjual makanan, tukang masak dan lainnya sudah dikelola oleh masyarakat setempat. Terkait SDM, masyarakat dan pengelola memperoleh pelatihan dari pemerintah seperti pelatihan Pokdarwis, pelatihan Manajemen Desa Wisata dan lain sebagainya.

Desa wisata Malangan dalam pengembangan dan pengelolaannya juga telah bekerjasama dengan bebarapa instansi dalam industri jasa pariwisata di Yogyakarta. Dalam meningkatkan kunjungan wisatawan, pengelola dan masyarakat sekitar mulai membangun dan mengembangkan wahana permainan Outbond. Untuk promosi, pengelola menggunakan media social seperti Instagram, Facebook, Blogger, dan melalui media elektronik seperti televisi, serta melalui media cetak seperti brosur.

\section{REFERENSI}

Adishakti, L. T. (2016) 'Pengantar pelestarian pusaka', pengantar pelestarian buaday.

Ariwibowo, M. E. (2019) 'Strategi Pemasaran Lembaga Pendidikan Tinggi Swasta', SCIENTIFIC JOURNAL OF REFLECTION: Economic, Accounting, Management and Business, 2(2), pp. 181-190. doi: 10.5281/zenodo.2628082.

Bikrunnafi'an, E. K. (2019) 'Pengaruh penggunaan teknologi informasi dan pengembangan sumber daya manusia terhadap strategi persaingan perusahaan pada pt. Bank muamalat indonesia tbk. Kantor cabang utama kediri', (1), pp. 13-43.

Dan, K. et al. (2020) '[3] , [4] , [5]', karuta dan pelestariannya.

Ii, B. A. B. (2012) 'No Title', pp. 7-33.

Khutniah, N. and Iryanti, V. E. (2012) 'Upaya Mempertahankan Eksistensi Tari Kridha Jati Di Sanggar Hayu Budaya Kelurahan Pengkol Jepara', Upaya Mempertahankan Eksistensi Tari Kridha Jati Di Sanggar Hayu Budaya Kelurahan Pengkol Jepara, 1(1), pp. 9-21.

Lubis Nurbaity Arlina (2004) 'Strategi Pemasaran Dalam Persaingan Bisnis', Persepsi Masyarakat Terhadap Perawatan Ortodontik Yang Dilakukan Oleh Pihak Non Profesional, pp. 1-14. Available at: http://repositorio.unan.edu.ni/298 6/1/5624.pdf\%0Ahttp://fiskal.kem enkeu.go.id/ejournal\%0Ahttp://dx. doi.org/10.1016/j.cirp.2016.06.001 \%0Ahttp://dx.doi.org/10.1016/j.po wtec.2016.12.055\%0Ahttps://doi.o rg/10.1016/j.ijfatigue.2019.02.006 \%0Ahttps://doi.org/10.1.

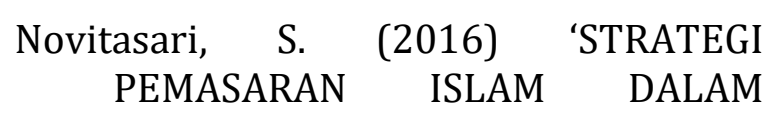


MENINGKATKAN LABA (Studi

Kasus Di Toko Fizaria Busana

Muslim Jepara)', Muhammad Ismail Yusanto dan Muhammad Karebet Widjajakusuma, p. 169.

Nunggalsari, R. N. and Keling, M. B. (1996)

'Kebijakan Pemerintah Kabupaten

Pacitan Dalam Pelestarian Museum

Buwono Keling di Kecamatan

Punung Kabupaten Pacitan', pp. 7593.

Sahputra, D. (2020) 'Manajemen

Komunikasi Suatu Pendekatan

Komunikasi', JURNAL SIMBOLIKA:

Research and Learning in

Communication Study, 6(2), pp. 152-

162.

doi:

10.31289/simbollika.v6i2.4069.

Samsuni : 113 (2017) 'Penulis adalah Kasubbag Keuangan pada Fakultas Syariah dan Ekonomi Islam UIN Antasari Banjarmasin. ? 113', Manajemen Sumber Daya Manusia, 17 no 31(31), pp. 113-124. Available at: http://ejurnal.staialfalahbjb.ac.id/in dex.php/alfalahjikk/article/view/1

9.

Setiawan, A. and Beni, I. (2012) 'Perencanaan Strategik Sistem Informasi pada Perusahaan Penerbitan dengan Metode Ward and Preppard: Studi Kasus pada Penerbit Rekayasa Sains Bandung', 11(3), pp. 308-325.

Tasruddin, R. (2015) 'Strategi promosi periklanan yang efektif', $A l$ Khitabah, II(1), pp. 107-116. Available at: http://journal.uinalauddin.ac.id/index.php/AlKhitabah/article/download/2623/2 473. 